\title{
The South Caucasus: Stage for a 'New Great Game' between NATO and Russia?
}

\section{Khayal Iskandarov, ${ }^{1}$ Greg Simons, $^{2}$ and Piotr Gawliczek ${ }^{3}$}

\author{
1 War College of the Armed Forces, Republic of Azerbaijan \\ 2 Uppsala University, Sweden \\ 3 University of Warmia and Mazury in Olsztyn, Poland
}

\begin{abstract}
The South Caucasus is one of the most important geostrategic regions between Europe and Asia, a playground for many regional and global actors with enduring interests. These interests have been clashing through the centuries. Each actor endeavors to impose its rules and tries to capitalize on the geostrategic benefits of the region. This article analyzes the main aspects, challenges, and prospects of cooperation between the countries in the South Caucasus and Russia and NATO. The authors describe the competition for power and influence in the region, the "Old Great Game," the regional state of affairs, and possible effects of the Russian factor on the South Caucasus-NATO cooperation. They illustrate Russia's security interests in the South Caucasus vis-à-vis NATO's enlargement policy, outline the reasons for the Alliance's reluctance to engage in the region actively, and current and future prospects of South Caucasus-NATO cooperation. NATO's presence is said to counterbalance the Russian military presence in the region, but how is this managed without antagonizing the incumbent government in Moscow and what is its contribution to resolving the so-called "frozen conflicts" in order to maintain the security and prosperity of the South Caucasus? The combination of competition and confrontation has been designated as the "New Great Game," with clear similarities and differences vis-à-vis the "Old Great Game." The authors question whether a "New Great Game" currently exists and apply comparative analysis, synthesis, inductive, and deductive methods to come up with conclusive answers.
\end{abstract}

Keywords: NATO, Russia, security, cooperation, frozen conflict, great power competition. 


\section{Introduction}

Though the South Caucasus occupies a small area on the world map, the scale of the interest in the region is much bigger than its geographical size. The collapse of the Soviet Union in 1991 fundamentally altered the geopolitical dynamics of the South Caucasus as each of the successor states sought to define their own national interests and policy priorities. ${ }^{1}$ Another effect of the collapse of the Soviet Union was that it permitted other powers to vie for influence in the former Soviet republics, which they were previously unable to do owing to the presence of strong hegemonic power of the Russian Empire and later the Soviet Union. ${ }^{2}$ In terms of its geopolitical and strategic importance the region has always been at the forefront of global powers' foreign policy. The hegemonic powers have been using it throughout history in order to exert their influence on neighboring areas. While the South Caucasus was previously considered to be on the periphery of the international agenda, after the dissolution of the Soviet Union and the subsequent formation of newly independent states, it became much more important both to its neighbors and influential non-regional actors. ${ }^{3}$ Today the South Caucasus is a diverse geopolitical region, which occupies a strategic point in transporting Caspian oil and gas.

However, the region is challenged with unresolved conflicts and socio-political and economic problems brought by the collapse of the Soviet Union. ${ }^{4}$ The protracted conflicts in the region have long been a source of tension for both Georgia and Azerbaijan. Though NATO does not take a direct part in resolving conflicts on the territory of a country outside the Alliance, the crises in the South Caucasus are largely influenced by the relationship between NATO and Russia.

This article seeks to engage in the discussion, through literature review and expert interviews, whether a "New Great Game" currently can be said to exist or not. In order to set the theoretical and conceptual scene, the first step is to understand what is meant by competition for power and influence. This includes a brief definition of what the "Old Great Game" involved as a benchmark for the current situation. This article outlines the perspectives and engagement of Russia and NATO - the primary foreign powers contesting for influence, the complexity of the current state of the interplay of the three countries that constitute the South Caucasus and the primary external actors of Russia and NATO, before

1 Sergey Markedonov, "Russian Policy Toward the South Caucasus: Security, Unity, and Diversity," in The New Geopolitics of the South Caucasus: Prospects for Regional Cooperation and Conflict Resolution, ed. Shireen T. Hunter (Lanham, MD: Lexington Books, 2017), 127-153.

2 Sarah O'Hara, "Great Game or Grubby Game? The Struggle for Control of the Caspian", Geopolitics 9, no. 1 (2004): 138-160.

3 Sergey Markedonov, "NATO Looks to the Caucasus," National Interest, May 17, 2012, https://nationalinterest.org/commentary/nato-looks-the-caucasus-6933.

4 Joshua Bartlett and Nino Samvelidze, Turkey and the South Caucasus: Prospects and Challenges for Cooperation," February 23, 2016, http://oval.az/turkey-and-the-southcaucasus-prospects-and-challenges-for-cooperation/. 
finally moving to the discussion whether a "New Great Game" actually exists. If it does, that also begs the question, what are the similarities and differences with the "Old Great Game"? We used the comparative analysis method to come up with more plausible outcomes for the region's better future. Comparative analysis, synthesis, inductive and deductive methods have been used to come up with conclusive answers.

\section{Competition for Power and Influence in Regions and the "Old Great} Game"

Various theoretical approaches allow us to study international relations and make sense of events, trends, and processes. Although such established theoretical lenses as realism, constructivism, Marxism, feminism, and others exist, ${ }^{5}$ neo-liberalism has been chosen as the means to make sense of this case study. Weighing pros and cons, considerations such as the specifics of the case, i.e., the study of the influence of international institutions on international security politics and relations, provides the tools with which to delve into the roles played by NATO versus Russia in the South Caucasus where the global political hegemony of liberal democracy prevails. Liberalism tends to expand its zone of influence, which, in the context of this article, is likely to bring it into competition or conflict as Russia views the region as a zone of its interests and influence.

As a theoretical approach to international relations, neo-liberalism draws upon the concepts of rationality and contracting, focusing attention on the central role played by institutions and organizations in the sphere of international politics. These organizations constantly weigh political interests and act as a balance between rule-based interaction and the unconstrained exercise of political power. One of the original criticisms of neoliberalism was by neo-realists claiming that they underestimated the role of domestic politics in international politics and cooperation. This has since come to be accepted by the neo-liberal camp. Attention focuses upon the issue of influence within international institutionalized settings of rules versus power. Neo-liberals approach institutions from a contractual perspective where they are used as 'solutions' to a given collectiveaction problem. Therefore, logically an institution begins the process by identifying and highlighting a strategic issue that needs to be addressed ${ }^{6}$ and communicates it. How does the competition for power and influence in regions manifest itself?

5 Tim Dunne, Milja Kurki, and Steve Smith, eds. International Relations Theories: Discipline and Diversity (Oxford: Oxford University Press, 2007), 392; Steve Smith, Amelia Hadfield, and Tim Dunne, Foreign Policy: Theories, Actors, Cases (New York: Oxford University Press, 2008), 572.

6 Eric Shiraev and Vladislav Zubok, International Relations, 2nd ed. (New York: Oxford University Press, 2016), 87-88; Lisa L. Martin, "Neoliberalism," in International Relations Theories: Discipline and Diversity, ed. Tim Dunne, Milja Kurki, and Steve Smith (Oxford: Oxford University Press, 2007), 110-126. 
One often-cited historical example, which is at times used as a yardstick for contemporary events and processes, is the Great Game. Scott notes that "the 'Great Game' was initially coined in the $19^{\text {th }}$ century to describe the geopolitical rivalry between the Russian and British Empires." 7 Both the British and Russian Empires thought of their actions and intentions in the old Great Game as being 'defensive' in nature. Britain sought to contain the Russian territorial advance, and Russia viewed the British threat as being equally real in nature. It was a complex game of intrigues and moves that sought to deny the opposing side the ability to gain new territories and influence. Queen Victoria was said to have remarked, "it is a question of Russian or British supremacy in the world." ${ }^{8}$ Can these sets of goals and circumstances of the $19^{\text {th }}$ century be an accurate analogy for what is currently happening?

However, some see the contemporary analogies of the Great Game as being overused and, in some instances, even misleading. The original $19^{\text {th }}$-century Great Game concerned classic imperialism and territorial annexation, whereas there is a significant difference in the New Great Game practice, which has become 'shorthand' for competition in influence, profit, power, and hegemony. ${ }^{9}$ To answer the question of whether a New Great Game exists or not, it is necessary to examine the specifics of the South Caucasus before moving on to the actions and motivations driving Russia and NATO.

\section{Russia's Security Interests in the South Caucasus vis-à-vis NATO's Enlargement Policy}

From the $18^{\text {th }}$ century until the break-up of the Soviet Union in 1991, Russia was the dominant power in the region. This region constituted Russia's and later the Soviet Union's southern border and was considered part of its "strategic backyard" or "zone of privileged interest" as the then President Dmitry Medvedev referred to it. In terms of politics, economics, and security, it is simply not feasible to separate the links and effects between Russia (especially the Northern Caucasus) and the South Caucasus. ${ }^{10}$ The disputes over the Soviet-era autonomous entities led to the wars in Nagorno-Karabakh, Abkhazia, and South Ossetia, bringing economic instability and security problems to the South Caucasus. These ongoing conflicts weakened the South Caucasus states and provided an opening for the regional and global powers to restart their competition for influence over the region. Starting from 1998, the formation of regional alliances

7 David Scott, "The Great Power 'Great Game' between India and China: 'The Logic of Geography'," Geopolitics 13, no. 1 (2008): 1-26.

8 David Fromkin, "The Great Game in Asia," Foreign Affairs 58, no. 4 (1980): 936-951, quote on p. 950.

9 Edwards Matthew, "The New Great Game and the New Great Gamers: Disciples of Kipling and MacKinder," Central Asian Survey 22, no. 1 (2003): 83-102.

10 Tracey German, Regional Cooperation in the South Caucasus: Good Neighbours or Distant Relatives? (Farnham: Ashgate, 2012), 107. 
among Turkey, Georgia, and Azerbaijan brought Iran into closer cooperation with Armenia and Russia. ${ }^{11}$ In the mid-2000s, the term "spheres of privileged interests" was used with the intention to signify a move away from 'influence' as it was much more specific and identifiable. In addition, policy moved away from an ideologically guided course to one that used pervasive pragmatism. ${ }^{12}$ Russia currently faces a number of different foreign actors and organizations seeking to expand their influence in the region, such as the US, Turkey, Iran, NATO, and the European Union. With a growing rift between Russia on the one hand and the US and the EU on the other in regard to Ukraine and Syria and an escalating conflict in Nagorno-Karabakh that might draw in regional powers, the South Caucasus may well become the third spot for employing the strategy of encircling Russia. ${ }^{13}$

To provide a comprehensive analysis of future challenges to NATO enlargement, it is also necessary to examine Russia's role in its so-called "near abroad" to counter the NATO expansion.

Russia has been concentrating on expanding strategic ties with its CIS neighbors, which she needs in order to re-emerge as a great power. "The South Caucasus is hence a region of critical national interest to Russia, which cannot simply shirk engagement there." 14 Among the factors that enable (potentially and actually) Russia to be a more effective regional actor are historical ties, institutional and demographic advantages, and the fact that the country physically borders the South Caucasus. ${ }^{15}$ In the wake of the Soviet Union's collapse in late 1991, several institutions were gradually established and sought in some ways to substitute the former mega-entity. Institutions such as the Commonwealth of Independent States (CIS), Shanghai Cooperation Organization (SCO), Eurasian Union, and the Collective Security Treaty Organization (CSTO) were based on the premise of the existence of a common history and common interests. However, not all of the newly independent states welcomed membership due to the perception of these institutions being Russian-led and under her influence and that Rus-

11 Orhan Gafarli, Arevik Anapiosyan, Khatuna Chapichadze, and Mehmet Fatih Öztarsu, "The Role of Global and Regional Actors in the South Caucasus," Journal of Conflict Transformation, June 2016, accessed April 16, 2019, http://caucasusedition.net/therole-of-global-and-regional-actors-in-the-south-caucasus/.

12 Dmitri Trenin, "Russia's Spheres of Interest, Not Influence," The Washington Quarterly 32, no. 4 (2009): 3-22.

13 Gafarli et al., "The Role of Global and Regional Actors in the South Caucasus."

14 Elkhan Nuriyev, "Facing Difficult Choices: The South Caucasus Between Russia and the European Union," Digest RIAC, https://bit.ly/2SrnxJk, 20 January 2015, accessed January 15, 2019.

15 Mitat Celikpala, "Escalating Rivalries and Diverging Interests: Prospects for Stability and Security in the Black Sea Region," Southeast European and Black Sea Studies 10, no. 3 (2010): 287-302, quote on p. 296. 
sia was seen as the former colonial power. ${ }^{16}$ Some authors, e.g., Abushov, ${ }^{17}$ argue that Russia's policies toward the South Caucasus constitute neo-imperialism. This occurs when independence is granted to another country, but it is still dominated through control of markets for goods and raw materials. The underlying logic is that Russia had ruled this geographic space for some 200 years and is not ready to free it from its influence. Moscow has a military-strategic, economic (especially in the energy field), as well as domestic and political leverage over the region. All three countries remain closely connected to the Russian economy through critical infrastructure, trade, investment, and remittances from permanent diaspora populations and migrant workers. ${ }^{18}$ So, Russia views the South Caucasus as its sphere of interest and an integral part of Russia's southern buffer zone. This makes the region an arena for Russian competition with the West and, to some extent, with the other two regional powers, Iran and Turkey. The Russian Military Doctrine of 2014 outlines the most serious military risks and threats facing Russia. Issues of particular relevance to developments in the South Caucasus are NATO enlargement in areas bordering Russia, the placement of NATO infrastructure in regions bordering Russia, and the establishment of regimes in states bordering Russia whose policies threaten Russian interests. ${ }^{19}$ However, as already stated, Russia is not alone in vying for influence in the South Caucasus.

Another entity seeking influence is NATO, an institutional vehicle for the USled West to attract former Eastern Bloc and Soviet entities under the banner of Euro-Atlantic integration and the promise to bring them from Russia's geopolitical orbit. Russia viewed NATO's advance as an unwanted intrusion into 'her' space and took the approach of trying to prove that those countries are 'unsuitable' and 'unreliable' partners. ${ }^{20}$ As the Russian researcher Vladimir Degoyev stated: "The West should realize that Russia has a vital interest in the South Caucasus. Russia and the West's goals in the region are the same. But there is a paradox that if NATO is Russia's neighbor in the South Caucasus, there will never be peace in this region. Therefore, some Russian political circles try to prevent the South Caucasus-NATO cooperation through various means. Russia has been exerting itself in order to incorporate all South Caucasus countries into both the CSTO and EEU due to its geostrategic location and natural resources. It wants to recreate the erstwhile world order in which Moscow again plays a major role,

16 Mikhail A. Molchanov, Eurasian Regionalisms and Russian Foreign Policy (Farnham: Ashgate, 2015), 23-47.

17 Kavus Abushov, "Policing the Near Abroad: Russian Foreign Policy in the South Caucasus," Australian Journal of International Affairs 63, no. 2 (2009): 187-212.

18 Khayal Iskandarov, The South Caucasus-NATO Cooperation (Riga: Lambert Academic Publishing, 2019), 57.

19 Gafarli et al., "The Role of Global and Regional Actors in the South Caucasus."

20 Anastassia Obydenkova and Alexander Libman, eds. Autocratic and Democratic External Influences in Post-Soviet Eurasia (Farnham: Ashgate, 2015). 
and its strategy is to cultivate a fear of Russia (as it has been Russia's historical culture) to force submission from their rivals." 21

NATO enlargement, its dividends, stakes, and repercussions have always occupied the heart of Western politics. Different candidates have been considered for membership; several have been admitted. The question of "Should Russia join NATO?" has also been the subject of discussion from time to time in the last decade of the $20^{\text {th }}$ century. Nevertheless, there was a feeling in Moscow that NATO's door, opened at times for others, was closed to Russia forever. Russia's NATO membership was not a serious option, while Moscow considered the Alliance a threat. As German Defense Minister Volker Rühe mentioned: "Russia cannot be integrated, neither into the European Union nor into NATO. If Russia were to become a member of the Alliance, it would blow NATO apart. It would be like the United Nations of Europe - It wouldn't work." Gardner claims that NATO does not want to involve Russia in the Euro-Atlantic space of cooperation as a full-fledged partner; on the other hand, it will not survive in its traditional shape. According to Russia, two factors are essential in the relations with NATO. First, the Alliance is still a challenge to Russia's security interests. Secondly, Moscow reckons that NATO's expansion to Russian borders negatively impacts the manifestation of Russia's "Big Brother" role. ${ }^{22}$ One author goes as far as to state: "it could be argued that NATO's very presence in the South Caucasus and its relationship with the three states led indirectly to the conflict in 2008 between Georgia and Russia and therefore has undermined efforts to initiate regional cooperation, by further dividing an already divided region." 23

We have to note that the period between Putin's second and third terms as a president was relatively calm in Russia's relations with the West. Combined with the reset with Russia beginning in 2009 by the administration of US President Barack Obama, other imperatives (the war in Afghanistan, Iran's nuclear program, the crisis in Libya) took precedence over NATO enlargement. At the same time, newly launched debates inside Russia about domestic political and economic modernization held out the prospect of Russia returning to the path of democratization and a more cooperative relationship with the West. In addition, NATO lacked the necessary consensus to push for Georgia's membership in the Alliance in the aftermath of the 2008 August war. In February 2010, Russia's new Military Doctrine identified NATO's attempt to extend its military infrastructure eastward to Russia's borders and add new members as key national security concerns, and Medvedev restated his opposition to the endless expansion of NATO. ${ }^{24}$ Alexei Bogaturov, Deputy Director of the Russian Academy of Sciences' Institute of International Security Problems, emphasized: "Russia does not want to return to the policy of confrontation with the West, but it also cannot concur

\footnotetext{
21 Iskandarov, The South Caucasus-NATO Cooperation, pp. 57-58.

22 Iskandarov, The South Caucasus-NATO Cooperation, p. 14.

23 German, Regional Cooperation in the South Caucasus, p. 152.

24 Iskandarov, The South Caucasus-NATO Cooperation, p. 42.
} 
with the systematic attempts of the US-NATO tandem to break through to a situation of absolute power supremacy over Russia." 25 Putin's third term began with a clear juxtaposition of Russia vs. the West as a conflict driven by different values systems. Two decades after signing on to the vision of Europe whole, free, and at peace with itself and its neighbors, Russia finally abandoned it. This break also manifested itself in Russian foreign policy, particularly in relations with the former Soviet states. Building on earlier Russian pronouncements about a sphere of influence and interests, and the danger posed by the West's geopolitical expansion, Putin elevated Eurasian integration, gathering the former Soviet states around Russia to the top of his foreign policy agenda for his third term. In his address on March 18, 2014, in which President Putin justified the annexation of Crimea, he underlined the humiliation Russia had suffered due to a series of hostile actions and broken promises by the West, including the eastward expansion of NATO. ${ }^{26}$

In fact, the more NATO expands closer to the Russian "sphere of influence," the more Russian military provocations intensify. According to Lohschelder, Russia grew increasingly concerned with NATO's eastward expansion and made it very clear that Georgia's inclusion in the Alliance would be considered an intolerable disturbance to the region's strategic stability. The proof of this statement is that Russia has already demonstrated that Georgia is in her sphere of influence and thus has a capacity to heat the frozen conflicts if she feels that the areas under her patronage are under threat. Paradoxically, NATO's reluctance to closely engage with NATO aspiring countries also detracts from regional security and contributes to Russia's assertiveness. Tedo Japaridze, chairman of the foreign relations committee of Georgia's parliament, said that if Georgia is kept waiting outside NATO, Russia will exploit the situation, and that would do little for the security and stability of the region. Another bone of contention is to "what direction NATO enlargement will push Russia?" It may be pointed out that Russia demonstrates little prospect of regaining her conventional force structure due to the change in her political system and fragile economy. However, Russia could still threaten NATO's significant interests. Kremlin's direction depends on both NATO's strategy as well as the course of the country's politics. Russia sees no need for US nuclear weapons in Eastern Europe and is concerned about NATO enlargement in her sphere of influence, namely in Georgia and Ukraine. Moscow believes that if these countries become NATO members, ballistic missiles would one day be deployed there, and that is why Russia will not hesitate to take adequate measures. ${ }^{27}$

It is also important to elaborate on Russia's individual approach towards each South Caucasus country. Armenia is a member of both the CSTO and EEU, which makes it utterly dependent on Russia. Beyond the political implications, Russia

25 Iskandarov, The South Caucasus-NATO Cooperation.

26 Iskandarov, The South Caucasus-NATO Cooperation, p. 43.

27 Iskandarov, The South Caucasus-NATO Cooperation, pp. 45-46. 
has been maintaining and periodically reinforcing its $102^{\text {nd }}$ military base in Armenia since 1992. The base is considered an essential asset for power projection in Moscow's hands and a precondition for its political and military dominance in the region. This has left Armenia in a difficult position and its profound vulnerability in relation to Russia affects the resilience of other nations in the region. Furthermore, the creation of Russian-Armenian joint forces reinforces Russia's military prowess in the region, leaving Yerevan little room for maneuver. Moreover, Russia holds significant influence in Armenia's defense and security sphere, which has, on several occasions, prompted impulsive decisions from Yerevan that contradict the officially declared agenda.

However, Moscow seems to have lost Georgia once and for all after the 2008 August war. Even if this is not the case, it will require an enormous effort over several generations to repair the damage. Moreover, after Russia's aggression, Georgia left the Commonwealth of Independent States (CIS), the last post-Soviet structure with which it was associated. By driving Georgia from the CIS, Russia lost legitimacy and influence over Georgia, which was exacerbated by the suspension of diplomatic ties.

Azerbaijan is also averse to being a member of Moscow-led organizations. Nevertheless, if Azerbaijan's membership is realized in Moscow-led organizations, Russia would achieve all its goals regarding the South Caucasus. Incorporating Azerbaijan, it can obtain a common border with Iran and deny Western access to Central Asia, which is detrimental to NATO's further engagement in both regions. If the West concedes the South Caucasus to Russia, its role as an energy corridor and commercial bridge between Europe and Asia will provide further leverage for Moscow to influence the EU and keep a tight grip on the broader Black Sea region, which includes several NATO members. ${ }^{28}$

The National Security Strategy that Putin signed into law on December 31, 2015, identified the United States and its allies as the principal threat to Russia, as the West seeks to hang on to its dominant position in the world. NATO enlargement continues apace, with the Alliance aspiring to a global mission. According to the new document, NATO undermines international security, international law, and arms-control treaties; acquires new military capabilities; and deploys its military infrastructure ever closer to the territory of the Russian Federation, threatening its security. ${ }^{29}$ In the post-soviet space, Georgia has been one of the most obvious examples that the West is experiencing confrontation with Russia.

In the National Security Strategy of the Russian Federation until 2020 and the Military Doctrine of the Russian Federation, Russia declared the right to apply military force when necessary within the borders of regional states in order to ensure its own security. According to some experts, this indicates that Russia remains the source of military-geostrategic threats to the post-soviet space, par-

28 Iskandarov, The South Caucasus-NATO Cooperation, pp. 58-59.

29 Iskandarov, The South Caucasus-NATO Cooperation, pp. 46-47. 
ticularly the Caspian-Black Sea basin and the South Caucasus. Moreover, according to the analysis of Russia's military doctrines of 2010 and 2014, Moscow's future strategy does not seem to include close cooperation with NATO. Thus, in the 2010 Doctrine, globalizing NATO is the number one external danger for Russia's security. Unlike the 2010 document, in the doctrine of 2014, the cooperation with NATO is not seen as a factor for stability, while the nature of the threats mentioned is the same. In this document, NATO was simply referred to as "a potential partner" for dialogue between equals. Although no specific country names are mentioned, the strategy of Russia's traditional influence zone is the core of the military doctrine of 2014. Therefore, since Armenia toes the Russian government's line and Azerbaijan's neutrality does not pose any security threat to Russia, the only country in which Moscow struggles to burnish its image is Georgia. Considering the failure of hard power policy aimed at dissuading Georgia from its pro-Western orientation, Russian authorities have begun to utilize so-called soft power in relations with Tbilisi. Understanding that arguing on foreign policy and security issues is senseless, as Georgia is not going to trade off its territorial integrity or change its political stance in regard to NATO and the European Union, Russian diplomacy is trying to pursue a policy of a dialogue based on the principle to "agree to mutually disagree" (when your partner acts within a certain framework). According to the proponents of this idea, Russia should adopt a new Georgia policy, one that would temper Moscow's passion for regime change in Tbilisi and instead employ direct outreach to the Georgian people. As examples of such straight-to-the-people approaches, Russian political analysts have cited President Barack Obama's video message congratulating Iranians on the holiday of Nowruz and his administration's easing of restrictions on travel and money transfers to Cuba. This new policy's goal would be to prevent the further alienation of Georgian political elites from Russia and help pro-Russian (or at least, Russia-neutral) forces come to power during the next electoral cycle. Some pro-Kremlin analysts claim this sort of policy is better and more advantageous than a defensive posture. ${ }^{30}$ How do experts see Russia's motivations and actions?

On January 25, 2018, an e-mail reply was received by one of the authors from the Director of Programs at the Russian International Affairs Council, Dr. Ivan Timofeev. He answered that there seem to be four foreign policy priorities for the Russian Federation in the South Caucasus: 1) Avoiding NATO membership of Georgia; 2) Strengthening status quo on Abkhazia and South Ossetia while making them more effective in terms of state management; 3) Developing the alliance with Armenia without spoiling relations with Baku; 4) Avoiding extensive influence of external players.

In another e-mail interview between the author and Sergey Markedonov, an expert on the Caucasus from the Department of Regional and Foreign Policy Studies at the Russian State Humanitarian University, it was assessed that "Rus-

30 Iskandarov, The South Caucasus-NATO Cooperation, pp. 57-60. 
sia has three major priorities in the South Caucasus: 1) support of Abkhazia and South Ossetia as a counterweight to Georgia's NATO and EU aspirations; 2) balancing between Armenia and Azerbaijan and engagement in the NagornoKarabakh conflict resolution; 3) ensuring its interests in the former Soviet Republics of Transcaucasia as a prerequisite for peaceful domestic development in the Russian North Caucasus." Furthermore, Markedonov noted in the e-mail:

Moscow follows a policy of "selective revisionism." While it has recognized the independence of Abkhazia and South Ossetia, the Kremlin has chosen not to support the aspirations of the unrecognized "Nagorno-Karabakh Republic." Strengthening its position as a regional leader, Russia actively cooperates with the West within the framework of the OSCE Minsk group. Unlike Georgia, the positions of Moscow and Washington on this issue have seen much more common ground and Moscow has managed to minimize the challenges to its regional dominance. Plans for further NATO expansion in the region remain frozen and Russia has only strengthened its role as a power broker in the $\mathrm{Na}$ gorno-Karabakh process. Moscow has also managed to provide the trans-border and anti-terrorist cooperation deterring Jihadist forces within Azerbaijan (and even Georgia, although in the latter case contacts are rather minimal). ${ }^{31}$

Both interviews make the Russian position in terms of its interests and priorities very clear. It includes keeping the influence of competing for external sources in the South Caucasus to a minimum, especially concerning potential NATO expansion. This is seen very clearly within a framework of geopolitical competition for influence in the region, but one where Russia currently possesses an advantage over its perceived rival, NATO.

The enlargement process can make NATO more robust, increasing its deterrence against possible external attack. Therefore, the membership of potential candidates would be highly beneficial. Incorporating new countries in the ranks of NATO would significantly boost their military capabilities. However, this approach might spark a conflict with Russia. It should be taken into account that Russia's strategic, economic, and ideological capacities to influence the security in the South Caucasus are immensely stronger than those of any other player. ${ }^{32}$

\section{NATO and the South Caucasus: Current and Future Prospects}

Since 1994, all three countries in the South Caucasus have been members of NATO's Partnership for Peace (PfP) Program. The stated reasoning and logic for engagement in the region are that it is intended "to support international efforts to promote confidence-building measures to foster a better environment for conflict resolution, primarily by helping the states of the South Caucasus to establish institutions that are better able to deal with the varied security challenges each country faces." 33 NATO attaches increased importance to the region. The

31 Email interview, 19 January 2018.

32 Iskandarov, The South Caucasus-NATO Cooperation, pp. 51-52.

33 German, Regional Cooperation in the South Caucasus, pp. 152-153. 
Alliance itself is not content with the escalation of tensions in the South Caucasus. All three countries are in Europe's Eastern Partnership, and the security in its neighborhood is in NATO's interest. However, due to a number of reasons, there has been less effort from NATO to contribute to the security situation in the South Caucasus actively.

Furthermore, NATO is not coherent in its policy towards South Caucasus. First and foremost, the Alliance is seemingly careful not to infuriate Russia. The Russian-Georgian war and the Ukraine crisis have made the West more reluctant and expansion into the South Caucasus is not expected to be on NATO's agenda in the foreseeable future. However, we can assume that NATO can counterbalance Russia and facilitate the overall integration of the region into NATO institutions through its partnership programs and mechanisms. While discussing the prospects of cooperation between the South Caucasus countries and NATO, regional factors have to be kept in mind. At the 2008 Bucharest summit, Russian President Vladimir Putin regarded the existence of a powerful military alliance in its "near abroad" as a direct threat to Russia's national security and national interests.

Notwithstanding this political rhetoric, President Bush strongly supported Ukraine and Georgia becoming NATO MAP members, while the United Kingdom, France, and Germany opposed this idea. ${ }^{34}$ The British judgment is that, although there was full support for both Ukraine and Georgia, the question of when they joined should remain in the balance. Germany and France said they believed that since neither Ukraine nor Georgia was stable enough to enter the program, then a membership plan would be an unnecessary offense to Russia. ${ }^{35}$ Germany is still skeptical, fearing that Georgian accession will drag the Atlantic Alliance into a confrontation with Russia. Thus, even if it is temporary, Russia has managed to prevent NATO's enlargement towards the post-soviet borders since 2008 and for the foreseeable future because Russian military intervention remains a credible threat to all post-soviet countries in its proximity.

NATO may be the sine qua non for security in the South Caucasus. However, this does not mean that the South Caucasus countries have to be full members. The most promising and perhaps single means of redressing the "security deficit" in the South Caucasus is through the gradual extension of NATO programs into the region. Regional states, including Armenia, are now gradually realizing that their relations with NATO are, in fact, concerned with how to select, develop, and incorporate NATO programs that will, together and increasingly over time, transform the regional security picture overall. ${ }^{36}$

While new global risks emerge, the security domain expands towards nontraditional security issues, which require a fast adaptation of traditional institu-

34 Steven Erlanger and Steven Lee Myers, "NATO Allies Oppose Bush on Georgia and Ukraine," The New York Times, https://nyti.ms/1TGdayY, April 3, 2008.

35 Erlanger and Myers, "NATO Allies Oppose Bush on Georgia and Ukraine."

36 Nasirov, Iskandarov, and Sadiyev, "The South Caucasus: A Playground between NATO and Russia?" 
tions, enlarging their responsibilities, tasks, and sometimes also the tools at their disposal. Energy security is prominent among those issues. Nowadays, energy has been more politicized, becoming an effective weapon for coercion and creating irreconcilable differences between energy owners and consumers. Since NATO admits that energy security is quickly becoming a growing concern for European security and will be one of the most important future challenges for Allies, the significance of the South Caucasus increases visibly. As a result of the political friction in the energy relationship between the EU and Russia in spring 2006 and later between Russia and Ukraine in January 2009, member states called for NATO involvement in energy security. ${ }^{37}$ But the lack of a consensus among members did not allow NATO's wider participation in energy security. Other institutions, such as the EU, have a key role to play and are more suited to resolving the major problems of investment and efficiency. But NATO could make a positive contribution to its members' energy security and, indeed, globally. Moreover, a lack of clarity about NATO's role and the reasons behind it, particularly in terms of its geographical role, could complicate NATO's relations with partner countries and other third parties (Russia in this case). The importance of ensuring energy security once again was underscored and endorsed by Allies in November 2010.

Paragraph 13 of NATO's Strategic Concept recognized the increased dependence of states on "vital communication, transport and transit routes on which energy security, international trade and prosperity depends." ${ }^{38}$ Others have assessed that the primary importance of Georgia and Azerbaijan to NATO is to secure the southern Caucasus nexus from Russian influence, secure energy supplies to Europe and limit interactions between Iran and Russia. However, "the Caucasus is not only a major flashpoint of frozen conflicts, but also presents itself as a limit for NATO's expansion on Russia's southern tier." ${ }^{39}$ The varied security interests and threat perceptions also complicate the region for NATO, where Georgia views Russia as a threat, Azerbaijan does not, and Armenia is a traditional ally. The main obstacles to a pivotal role for NATO in energy security within the Caspian region are:

- A lack of means and tools at NATO's disposal, which impedes the implementation of the intentions expressed in NATO's Strategic Concept;

- Russia's reluctance to engage in a joint effort with NATO. Any action that the Alliance would implement, especially involving the military, could

37 Nasirov, Iskandarov, and Sadiyev, "The South Caucasus: A Playground between NATO and Russia?"

38 Opening speech by H.E. Daniel Cristian Ciobanu, Ambassador of Romania to Azerbaijan to the International workshop on ensuring energy security in the Caspian basin and NATO's role in protecting critical energy infrastructure, Baku, November 22, 2012.

39 Paul Antonopoulos, Renato Velez, and Drew Cottle, "NATO's Push into the Caucasus: Geopolitical Flashpoints and Limits for Expansion," Defence and Security Analysis 33, no. 4 (2017): 366-379. 
trigger the Russian reaction to counterbalance the Euro-Atlantic presence in such a vital region to protect its national interest;

- Discord within NATO for a greater NATO commitment to energy security;

- Weak cooperation on energy security with Caspian partners. ${ }^{40}$

However, the ever-increasing need for diversification of the energy sources and the cooperation in energy transit issues makes the West attach too high importance to the South Caucasus region (Azerbaijan-Georgia-Turkey corridor) as a reliable transit route avoiding Russian and Iranian territories. The Baku-TbilisiCeyhan oil pipeline and Baku-Tbilisi-Erzurum natural gas pipeline represent a step forward in this cooperation, especially combined with the upcoming TANAP and TAP projects. The further development of the Caspian region will have a considerable impact on the world's strategic balance and a key question of receiving access to Central Asian resources. South Caucasus' role in ensuring the energy security of Europe is also welcomed by the US, and the White House strongly supports the Azerbaijan-initiated Southern Gas Corridor project, which will carry the "Shah Deniz II" gas to European consumers. State Secretary Kerry stated that "this project was a very important step with respect to Europe's long-term strategic interests and frankly, to try to diversify the sourcing of energy, which is important." ${ }^{41}$ As a result of this policy, the existing tools and efforts for new initiatives towards the diversification of energy supply will improve Europe's energy security and the security of the Alliance as a whole. NATO's role here is to add value to EU energy security and pave the way towards the energy security of the Alliance.

Considering the strategic nature of the region, NATO should keep a close eye on developments in the South Caucasus, both politically and economically. It has been noted that NATO provides a means and a mechanism for the West to attempt to integrate the region into its sphere by transferring the principles (values and norms) of democratic governance and the rule of law ${ }^{42}$ to bring the South Caucasus in line with those of liberal democracy. The general approach attempts to create and maintain 'like-minded' states to balance Russia's common historical experiences and interests' policy. In addition, Russia has shown that it uses frozen conflicts and energy as tools to push NATO away from its borders and weaken its cohesion. If we consider all non-NATO countries on Russia's European periphery, we would see that only Finland, Sweden, and Belarus do not have any

40 Nasirov, Iskandarov, and Sadiyev, "The South Caucasus: A Playground between NATO and Russia?"

41 Nasirov, Iskandarov, and Sadiyev, "The South Caucasus: A Playground between NATO and Russia?"

42 Pierre Jolicoeur and Frederic Labarre, "NATO's engagement in the South Caucasus: Looking for Energy Security or Expanding Norms and Values?" in Reassessing Security in the South Caucasus: Regional Conflicts and Transformation, ed. Annie Jafalian (Farnham: Ashgate 2011), 163-167. 
conflicts in their territories. The first two are neutral countries, and the latter is a CSTO member. We deduce that the membership for all aspiring countries has become far-fetched, even wishful thinking for the foreseeable future. However, that does not necessarily mean that NATO should stay on the sidelines on the issue of the conflicts if their continued presence is an important issue for the overall European security architecture. ${ }^{43}$

As the key to NATO, the United States, in its 25 years of involvement in the region, evaluates its position in the South Caucasus as consisting of 'important' rather than 'vital' interests. They have been involved in some positive changes in the area but have also faced significant challenges and obstacles. "However, some US-supported initiatives proved too ambitious because they underestimated the challenges facing the South Caucasus states and lacked adequate resources." 44 In addition, US policy needs to contend with Russia's dominant position there and her opposition to US engagement in the region. Each of the three countries in the South Caucasus is undergoing gradual change over time, with periodic moments of conflict and cooperation, which are influenced externally. This has led some commentators to remark on a New Great Game taking place in the region. This perception is reinforced by some recent hawkish op-eds that have appeared in influential newspapers in the United States, such as Stephen Blank's (senior fellow at American Foreign Policy Council) opinion that appeared in Washington DC's newspaper The Hill. Blank criticizes what he terms as "mistaken lobbying" of US foreign policy in the Caucasus that he assumes benefits Russian policy and interests there by the lack of challenge to Russian hegemony. He ultimately calls for the US to "beat the Russians at their own game." ${ }^{45} \mathrm{Hard}$ rhetorics such as Blank's are likely to increase tensions in the region between the US/NATO and Russia as it seemingly confirms to the Russians the subversive intent in the region. But this does not answer whether the perception of the policy elites of NATO/US and Russia of their interests and security are at an equal level of urgency and importance.

Experts were also interviewed by e-mail by the authors to understand the political and policy aspects of the geopolitical/geo-economic situation in the South Caucasus and the wider region and how events may influence pragmatic thinking and assessments. The first e-mail interview was with the head of research at the European Geopolitical Forum, a formerly with NATO, George Niculescu. His detailed reply was received on February 1, 2018.

43 Nasirov, Iskandarov, and Sadiyev, "The South Caucasus: A Playground between NATO and Russia?"

44 Eugene Rumer, Richard Sokolosky, and Paul Stronski, US Policy Toward the South Caucasus: Take Three, Carnegie Endowment for International Peace, May 31, 2017, accessed 12 January 2019, https://bit.ly/2rbWK9A.

45 Stephen Blank, "US in the Caucasus: Beat the Russians at their Own Game," The Hill, January 28, 2018, https://thehill.com/opinion/international/370980-us-in-thecaucasus-beat-the-russians-at-their-own-game, accessed 30 August 2019. 
NATO-Russia competition in the South Caucasus is only secondary to the main thrust of the current confrontation between Russia and the West. On the one hand, from a Western perspective, the South Caucasus is currently much less important than it was in the past (just compare the NATO summit joint statements in Istanbul, 2004, and Warsaw, 2016). On the other hand, strategically speaking, if you look at the last 200 years of history of invasions against Russia (Napoleon, Hitler), and, respectively, against Eastern Europe (Stalin), the South Caucasus region has only been a marginal war-front, in contrast to the Baltic states, Belarus, Poland, Ukraine, and Romania being the frontline. This is still visible today in the way NATO has construed its strategic response against Russia's perceived aggressiveness in Ukraine.

NATO's interests in the South Caucasus are rather limited and mainly linked to NATO's self-restrained regional role, which is mostly limited to soft security cooperation, e.g., defense and security sector reforms. The following factors drive these interests:

1. NATO refocuses on deterrence and defense of the territory of its Eastern members against a resurgent Russia;

2. a decrease of the strategic priority of the region in the wake of unwinding the ISAF operation in Afghanistan;

3. a limited European interest for maintaining the security of energy flows (oil and gas) from Azerbaijan to Europe, via Turkey, due to decreasing fossil fuels demand on European markets, and alternative energy projects (including the Russia-led Turkish Stream and Nord Stream 2 projects).

NATO's interest in the South Caucasus region has been further reduced by the tacit Russian-Turkish partnership of convenience, which is basically motivated by both parties' focus on different fronts: Russia's engagement in the geopolitical confrontation with the West over Ukraine and its military involvement in the Syrian war, while Turkey has been absorbed by the fluid evolutions in the Middle East, particularly in Syria and Iraq.

However, the geopolitical competition between Russia and the West over Ukraine may have a negative impact on the South Caucasus in the future: either it may turn the current de facto situation into a new de jure geopolitical reality (via a "new deal on European security"), or it may push the whole region into the swirl of instability around Ukraine. Three factors seem decisive for this analysis:

1. Russian progress in ensuring geopolitical control of Ukraine's foreign and security policy may tend to support the first option. Otherwise, faced with a stronger pushback in Ukraine, Moscow might have to expand its confrontation with the West in the South Caucasus.

2. Turkish tacit acceptance of Russian incursions in Ukraine may also favor the legalization of the status quo in the South Caucasus, while Ankara's brazen reaction, via NATO or directly, may dramatically raise the risk of instability in the South Caucasus. 
3. EU's growing distance from US confrontational policies against Russia is also favoring the first option. This may be driven by the EU's perceived military weakness (strengthened by Brexit, and the preoccupation with Mediterranean security threats and risks), its stronger economic interests (buying energy and exporting manufactured products) in Russia, its expected expansion of trade and investments with China within the context of the Belt and Road infrastructure projects, and unreliable and controversial US policies (which have also sapped the very credibility of US leadership in NATO).

In summary, the South Caucasus might be a good starting point for a talk on a "new deal on European security" due to:

1. limited NATO/US interest for the region;

2. increasing Western European members' (France, Germany, Italy, and Spain) interest to find a decent modus vivendi with Russia;

3. Turkey's partnership of convenience with Russia;

4. Russia's own interest to break the Western sanctions against its incursions in Ukraine and restore its trade and investment relations with the EU (bilaterally and via the Eurasian Economic Union).

Some important observations include the remark that what is happening in the South Caucasus is part of the larger geopolitical and geo-economic picture. Although the South Caucasus is pictured as somewhat of a secondary concern, this can change depending on events and circumstances of the strategic view on competition and conflict between Russia and NATO. As such, the situation is potentially very volatile in the region as what transpires there is not necessarily originating in the South Caucasus. Others see the situation differently. The second person interviewed by e-mail was Magnus Geir Eyjolfsson, a Public Diplomacy and Civil Society Expert with the NATO Liaison Office in Georgia. An e-mail reply was received from him on February 2, 2018.

There is certainly not a "new great game" going on in the South Caucasus from NATO's perspective. For the Alliance, it is all about securing and preserving peace in its neighborhood. NATO's policy towards the South Caucasus is enshrined in the Partnership Programs that have been in place since the mid-1990s. However, a distinction has to be made between the partnership with Georgia on the one hand and the partnerships with Armenia and Azerbaijan on the other.

NATO deems the South Caucasus to be strategically important to the Alliance for many different reasons. The region borders the territory of a NATO member state while it also offers useful alternative transit options for transporting supplies to and from the NATO-led force in Afghanistan.

The Allies and their partners in the South Caucasus face the same security challenges, such as terrorism and the proliferation of weapons of mass destruction. Energy security is another important security issue of shared concern. The 
South Caucasus sits on key oil and gas transit routes and has significant oil and gas reserves of its own.

One serious concern is the protracted conflicts in the region. While NATO does not seek a direct role in resolving these conflicts, the Alliance supports the efforts of other international organizations, which have specific mandates for their mediation roles. The peaceful resolution of the conflict is a core value of NATO and is at the heart of the commitments that NATO's partners in the South Caucasus undertook when they joined the Partnership for Peace.

Beyond cooperating on security and defense-related capacity building and reform, NATO and its partners in the South Caucasus work together in other areas such as border security, cybersecurity, and disaster preparedness and response. They enhance Euro-Atlantic and international security, peace and stability, promote regional security and cooperation, and promote democratic values and reforms. In essence, when the neighbors enjoy peace and stability, NATO countries are enjoying more safety. In addition, partnerships enhance support for NATO-led operations and, in some cases, prepare interested eligible nations for NATO memberships.

One of the partnerships' core elements is that the respective partner country determines the level of cooperation-the pace, scope, intensity, and focus. NATO fully respects the sovereignty of its partner states and therefore does not impose any elements to the cooperation on the partner countries.

Opponents of NATO enlargement, who have consistently argued that it needlessly provokes Russia, costs too much, dilutes Alliance unity and distracts NATO from its original mission, will argue that it is not too late to halt the process now, or at least that it should be suspended. After a myriad of pledges by the Alliance leaders, both individually and through the Alliance, NATO's door still remains open. A decision to stop the process would badly damage NATO's credibility and undermine its reputation throughout the aspiring regions. Understandably, today many allies remain ambivalent about future enlargement. The current aspirants face serious challenges. Despite the commitment at the 2008 NATO Bucharest summit that Georgia will become a member, many allied capitals harbor deep suspicions about whether this statement is credible. However, it should be noted that during the debates on NATO enlargement in the 1990s, policymakers in allied capitals, including Washington, scoffed at the idea of the Baltic States joining the Alliance, arguing that such a step was too provocative and destabilizing. They were wrong. The security, stability, and predictability of embedding the Baltic states within NATO are what has allowed for the normalization of the relations between these former Soviet republics and Russia. At that time, each of these nations also had Russian troops stationed on their territory. Today, Estonia has a border treaty with Russia, Latvia is cooperating with Russia on facilitating transit to Afghanistan, and Vladimir Putin has welcomed Lithuania's leaders in Moscow. Thus, after North Macedonia is admitted to NATO, the allies will take 
stock of some other countries for those the membership is currently a pipe dream. ${ }^{46}$

Some of Niculescu's observations have also been raised, such as the influence of processes and events external to the region and the geopolitical and geo-economic aspects of NATO's engagement in the region. Yet, the quality of the partnership described involves a mutual relationship where NATO transfers knowledge and values to the respective countries of the South Caucasus. There is a strong denial of any sort of a New Great Game taking place, which has some negative connotations embedded in $19^{\text {th }}$-century history. The remark of possible future membership of the South Caucasus countries is likely to reinforce some perceptions of a geopolitical 'game' taking place in the region that works against Russian goals and interests. Eyjolfsson does describe the great diversity in terms of the relationship and the levels of engagement between NATO and the three countries, which have quite different national interests and goals.

\section{A "New Great Game" in the South Caucasus?}

According to its strategic concepts, NATO's vested interest in the South Caucasus is to maintain security through cooperation and secure its access to Caspian energy resources. After Bulgaria and Romania joined NATO in 2004 and then the European Union in 2007, the South Caucasus began to be considered as a new frontier for NATO and the whole structure of European security. ${ }^{47}$ Apart from this, for NATO and its members, the role of the South Caucasus is extremely high in terms of Eurasian security as well. According to Tamaz Papuashvili, the South Caucasus is the center of economic interest and an important transportation corridor. Other factors also have fueled interest in the region. Foremost among them are its natural resources (the Caspian basin) and proximity to three major and ambitious Eurasian states: Russia, Turkey, and Iran. The region plays a crucial role as a transport and energy corridor. Today Europe relies heavily on Russian oil and natural gas. However, the EU is set to prevent Russia from wielding energy as a coercive tool, and the Caspian basin has the utmost importance in this policy. ${ }^{48}$ Azerbaijan-Georgia-Turkey corridor is a critical strategic link between Europe and Central Asia, challenging Russia's current stranglehold on energy resources. This corridor includes the production and transportation of hydrocarbons.

The paths of the three South Caucasus republics have been different in terms of their geopolitical orientations, with Armenia being a CSTO member, utterly dependent on Russia and having the least engaged relations among the South Caucasian states with NATO, Azerbaijan pursuing an independent policy regard-

46 Iskandarov, The South Caucasus-NATO Cooperation, pp. 52-53.

47 Markedonov, "NATO looks to the Caucasus."

48 Eric S. Thompson, Turkish Influence in the South Caucasus and Levant: The Consequences for NATO and the EU (Monterey, CA: Naval Postgraduate School, 2013), 37. Retrieved from https://bit.ly/2JC3KWB. 
ing global powers, and Georgia demonstrating a pro-NATO position. The lack of diplomatic relations between Armenia and Azerbaijan due to the NagornoKarabakh conflict, lack of NATO presence, and Russia's increased assertiveness in the region are central elements of understanding ongoing policy in the region. What we comprehend from this policy is that the South Caucasus is a complex playground between Russia and NATO. Though NATO has a limited role, Russia is very much engaged in the region, as recent and ongoing conflicts illustrate, and has retained substantial leverage and influence for a long time. After the collapse of the Soviet Union, Russia has been set to dominate the post-soviet countries and declared this strategy a priority of its foreign policy. Russia's presence in the region is apparently felt, including its military participation in Armenia and Georgia's breakaway entities.

Nevertheless, the way common interests might be translated into joint opportunities depends not only on Russia's policy towards the South Caucasus but also on how Russia-NATO relations evolve. That is why national security interests and foreign policy goals of these states have to be part of the bargaining process, despite their position regarding Russia and NATO. ${ }^{49}$ Some commentators remark that the future of the South Caucasus depends upon its ability to overcome the geopolitical rivalry of the foreign actors with influence in the region and to establish a functional working relationship with those key actors. ${ }^{50}$

However, a functional working relationship between the competing powers seems at current a remote opportunity for a number of reasons. NATO and the US have been working to reduce Russia's physical presence and influence in the region through such lofty ideals as human rights, the rule of law, and democracy. There is a significant dissonance observed in how allies and opponents are characterized on these points. The situation has led to accusations by Russia of double standards and that the US is implacably hostile to Russian interests. One institutional mechanism that was given as an example is the GUAM (Georgia, Ukraine, Azerbaijan, and Moldova) format, characterized by Lieven as US-sponsored anti-Russian pact. ${ }^{51}$ Van der Pij| ${ }^{52}$ adds that GUAM was established to integrate Azerbaijan and Georgia's security structures into the Euro-Atlantic security structures by encouraging the countries to leave CSTO. The crucial point in formulating NATO's future engagement in the region is that membership in NATO is not an issue. NATO's wide variety of programs serve to transform the regional security picture overall - with or without membership. PfP is an invalu-

49 Nasirov, Iskandarov, and Sadiyev, "The South Caucasus: A Playground between NATO and Russia?"

50 Martin Kremer, "European Partnership and the South Caucasus: Framework Condition for a Grand Bargain in 2025?" in Future Scenarios for the South Caucasus, Caucasus Analytical Digest No. 19 (13 August 2010): 15-17.

51 Anatol Lieven, "The (Not So) Great Game," The National Interest 58 (Winter 1999/ 2000): 69-80.

52 Kees van der Pijl, "Global and Local Rivalries in NATO's push towards the Caucasus," Spectrum: Journal of Global Studies 1, no. 1 (2009): 33-52. 
able tool in building political and military bridges between NATO members and partner nations. ${ }^{53}$ PfP proved to be a very successful mechanism in promoting and developing defense cooperation and military interoperability between NATO and the South Caucasus countries through its activities.

Nevertheless, the extent and depth of cooperation with Azerbaijan and Georgia are of a different order than that with Armenia. The furthest extent of the penetration of the influence of Western institutions was assessed as being in Georgia, up to the point of the 2008 war when Georgian President Mikheil Saakashvili attempted to retake South Ossetia by military force, which prompted Russia's strong and decisive reaction aimed at putting that geopolitical trend in check. ${ }^{54}$ Georgia had unanimously articulated that it was pursuing NATO membership since 2003, when Saakashvili came to power, until August 2008 when the war broke out. As a corollary to that war, Georgia has become more prudent in its relations with Russia. A long period of time has elapsed since that event; yet, Georgia is not as close to NATO membership as it was ten years ago, before the August war, despite a strong presence in NATO operations and solid credentials in meeting the Alliance's military and political standards. In fact, Russia demonstrated its continued presence in the region through its military actions in Georgia. At the same time, NATO demonstrated to all the South Caucasus countries that it was not willing to fight Russia for the sake of Georgia's territorial integrity, no matter how eager it was to join NATO.

This signal was immediately and accurately read by a careful Azerbaijan, which thereafter strengthened the multi-vector nature of its foreign policy amidst the region's geopolitical rivalries and joined the Non-Aligned Movement (NAM) in 2011. ${ }^{55}$ By joining NAM, Azerbaijan declared that it is not seeking membership of either NATO or CSTO at the moment. However, the Republic of Azerbaijan, with its growing international prestige, attaches great importance to the development of its relations with NATO. Today, the international experts highly appreciate the steps taken by Azerbaijan in ensuring regional and global security, safeguarding its interests on reciprocal bases. ${ }^{56}$ Azerbaijan is deemed NATO's most reliable partner in the region, though it has no direct intention to join the Alliance. "Azerbaijan is one of the most important, active, and long-term partners of NATO. We are actively developing a political dialogue with Baku," stated the Assistant Secretary General of NATO Sorin Ducaru, speaking at the conference marking the $20^{\text {th }}$ anniversary of the program "Partnership for Peace" on

53 Nasirov, Iskandarov, and Sadiyev, "The South Caucasus: A Playground between NATO and Russia?"

54 Van der Pijl, "Global and Local Rivalries in NATO's push towards the Caucasus."

55 Nasirov, Iskandarov, and Sadiyev, "The South Caucasus: A Playground between NATO and Russia?"

56 Nasirov, Iskandarov, and Sadiyev, "The South Caucasus: A Playground between NATO and Russia?" 
April 11, 2014. ${ }^{57}$ As NATO's reliable partner, Azerbaijan's cooperation with the Alliance extends to many areas, including fighting against terrorism, regional security, and contribution to international security, particularly Azerbaijan's support to NATO operations. In this regard, Azerbaijan aspires to achieve military standards and get closer to NATO's military institutions. NATO's political priorities and security interests chime with Azerbaijan's national interests. Further improvement of multilateral relations is the main guarantor of peace and security in the region.

The arguments of the South Caucasus-NATO relations can be grouped as follows:

- It increases the confidence in the security of the South Caucasus region;

- It ensures the security of oil and gas production and transportation;

- The most important problems in the region, the so-called "frozen conflicts," might be solved by peaceful means;

- $\quad$ Armed Forces become interoperable with NATO Forces.

If the South Caucasus-NATO cooperation acts as a guarantor of the region's security, then the nature of all possible dangers should be analyzed. So, what dangers are there in the region? The very fact that Western policy in the region backs their energy goals means that it already clashes with Russia's national interests. Obviously, in the current socio-political situation, the possible dangers most probably stem from countries whit economic and political interests contradicting those of NATO. Thus, to understand the nature of threats, one needs to determine the areas of conflicting interests. The Caspian oil and gas fields are the first and foremost reason. In this domain, NATO's interests clash seriously with Russian interests, and the latter has been using the "frozen conflicts" for decades in order to keep the region and its oil and gas infrastructure under threat. In fact, these conflicts, interspersed with numerous asymmetrical threats in the region, present a challenging environment on NATO's Eastern flank. Russia is playing a dual game in the South Caucasus, both stabilizing and destabilizing the region at the same time.

On the one hand, there is Russia, the conflict-mediator who brokers ceasefires and seeks to resolve the South Caucasian conflicts via its mandate of cochair of the OSCE Minsk Group. On the other hand, there is Russia that is seen by some as a provoker. After mutual provocations leading up to the 2008 war with Georgia, Russia recognized two of Georgia's breakaway regions as independent states and is still militarily present in these territories. ${ }^{58} \mathrm{~A}$ certain amount of leverage is used by Russia in maintaining frozen conflicts and "controlled instability," such as the continued presence of Russian security forces in

57 Khayal Iskandarov, "The Road of Integration of Azerbaijan into NATO (1994-2014)", The Caucasus and the World 19 (2015): 85-90.

58 Nasirov, Iskandarov, and Sadiyev, "The South Caucasus: A Playground between NATO and Russia?" 
the region, serving geo-energy interests, and retaining the geopolitical status quo. ${ }^{59}$ Nuriyev notes that "Moscow clearly continues to influence the South Caucasus nations in various, subtle ways so as to orchestrate a conflict scenario settlement that will not only serve Russian strategic interests but also, in the end, gratify Armenia, Azerbaijan, and Georgia. Such a regional perspective best illustrates Russia's broad interests, of which Putin's Eurasian Union is but one important part." 60

Russia's policy and actions in the South Caucasus aim to prevent or limit other foreign actors' influence in the region when it is viewed as contrary to her security and economic interests. ${ }^{61}$ Today Russia accuses NATO of destabilizing the Caucasus region with the joint exercises in Georgia but has itself stationed permanent military bases in Armenia, as well as in the separatist regions of South Ossetia and Abkhazia. Emboldened by Russian support, Armenia still keeps Nagorno-Karabakh under its influence. However, the West does not have an effective political or military tool to balance Russia's military in Armenia. The unbalanced and overwhelming Russian military presence in Armenia creates a threat to planned Western oil and gas infrastructures and pipelines. ${ }^{62}$ Yet, Russia has been using its role as a mediator for advancing its own interests rather than for actual conflict resolution. As long as the three South Caucasus states are divided, Russia can influence them. It is not a secret that South Caucasus conflicts serve Russia as political leverage over Georgia, Armenia, and Azerbaijan. In a nutshell, Russia has been applying a divide and rule policy through protracted conflicts. Indeed, the current status quo is clearly beneficial to Russia's interests, preserving an economic and military sphere of influence while preventing any of the South Caucasian states from looking towards NATO.

There have been different academic arguments both for and against the proposition that there is currently a New Great Game underway in the South Caucasus. We will first summarize the changes in the environment that potentially could support the thesis of a New Great Game. Trenin states that Russia's North and South Caucasus policy centered upon suppressing the insurgency in Chechnya, which was considered as being largely fulfilled by $2004 . .^{63}$ All other issues were treated as being of secondary or tertiary importance. There was a shift in goals after Chechnya was largely pacified, which centered on resisting the spread of Western and US influence in the Commonwealth of Independent States. "From this perspective, Armenia featured as Russia's regional bulwark

59 Abushov, "Policing the Near Abroad: Russian Foreign Policy in the South Caucasus."

60 Nuriyev, "Facing Difficult Choices: The South Caucasus Between Russia and the European Union."

61 Markedonov, "Russian Policy Toward the South Caucasus: Security, Unity, and Diversity."

62 Mahir Khalifazadeh, "The South Caucasus: Obama's Russia 'Reset' and Putin's Doctrine," CESRAN International, https://bit.ly/2TjADNi, July 27, 2014.

63 Dmitri Trenin, "Russia in the Caucasus: Reversing the Tide," The Brown Journal of World Affairs 15, no. 2 (Spring-Summer 2009): 143-155. 
and security base; Georgia, a pro-US implantation within Russia's sphere; and Azerbaijan, a nominally neutral battleground in Russian-US competition." 64 This situation sets the scene for continued competition for influence in the region based especially on energy issues and geopolitical spheres. The Old Great Game involved the attempt to limit the territorial expansion and influence of one Empire, which was seen as a direct threat to another Empire.

As early as 1994-1995, some scholars suggested that a New Great Game had begun. This New Great Game's logic was brought about by the collapse of the Soviet Union, resulting in a security and influence vacuum, which meant that a lot of 'new' territory was opened up to possible external actors. However, there was some caution in applying an absolute blanket use of the analogy to the whole picture as there were regional variations and differences appearing in the CIS. One of the differences noted is that in the original Great Game, little attention was paid to the local elites, beyond using them as figureheads and proxies in the rivalry. The New Great Game continues to try and manipulate the local elites; however, the local populations have a much more pronounced sense of self-identity (even if it is not a coherent national one) ${ }^{65}$ Other differences and nuances were also observed:

- The original Great Game involved not only armies but also European adventurers, seeking to penetrate and control previously unexplored territory.

- The process was driven not only by aspirations for territorial expansion and military advantage but a strong desire to open up new trade and markets. Therefore, it included not only a diplomatic maneuver but also commercial penetration. In the New Great Game, aid is disguised as an investment and is a means to have a say in regional affairs, where trade is a lever of economic reward or coercion.

- The Old Great Game involved two rival powers with a parallel but noncontiguous border expanding towards each other over what was considered as being no-man's land. The New Great Game involves Russia seeking to maintain influence against Western powers in order to retain a buffer zone. ${ }^{66}$

These observations reveal some distinct subtleties that exist between the Old and New Great Games and how the power rivalry was conceived and waged. Cuthbertson does make the additional observation that concerns the variation of how the New Great Game is managed. "If Moscow's policies in the Baltic States reveal Russian behaviour at its most subtle, Russian power is at its most naked and abusive in the Transcaucasus. Here Russia plays the new Great Game

64 Trenin, "Russia in the Caucasus: Reversing the Tide."

65 Ian Cuthbertson, "The New Great Game," World Policy Journal 11, no. 4 (Winter 1994/ 1995): 31-43.

66 Cuthbertson, "The New Great Game." 
with all the panache, flair, and ruthlessness that it displayed in acquiring its empire in the $19^{\text {th }}$ century. ${ }^{\prime 67}$ Other scholars have made observations that in part coincide with Cuthbertson. There are a number of constraints and restraints on the states of the South Caucasus, both historical and contemporary, which limit their freedom of action. Anderson notes that the region has become a classic buffer zone, with some parallels to the original Great Game, where powerful states have delimited the region for their own purposes. "Thus, as a buffer zone, there is an ever-present danger of fragmentation and either collaboration with or more likely subservience to a regional or outside power." ${ }^{\prime 8}$ Some other scholars and commentators see the analogy as being overblown.

Anatol Lieven downplays the Great Game analogy because "the importance of the Caspian region to American foreign policy is grossly exaggerated." ${ }^{69}$ It was only the demise of the Soviet Union that permitted the occasion to become engaged in the region. A number of factors in the mid-1990s influenced a change in the US approach, such as the oil and gas reserves in the region, deterioration in relations between the US and Russia, growing instability in Russia, and strengthening the ties between the US and Turkey. The result of these factors "was an ambitious strategy of attempting to 'roll back' Russian influence in the region and to replace it with a new, more benign American hegemony." 70 Other scholars have also noted that the collapse of the Soviet Union in 1991 opened the possibility for the US and Western Europe to gain access to energy reserves, which had been forecasted as enormous. ${ }^{71}$ What Lieven saw was not a clash of armies and diplomats to divide and occupy territory for economic and military advantage, but rather an attempt to 'conquer' countries by imparting norms and values to make them more like the US gain geopolitical and geo-economic advantage through influence.

Unlike the US/EU approach of trying to change the region's values and norms, which is potentially a threat to the political and economic elites of the region, Russia applies a regime stability approach. The result is that the more the West attempts to 'democratize' the region, the more likely the regimes in the region will pivot to powers such as Russia and China driven by the instinct of regime survival. ${ }^{72}$ "In this Great Power rivalry, Russia has at present tactically outmaneuvered NATO in the Caucasus and made it virtually untenable for the alliance to maintain a permanent presence in the region, despite strong efforts by the US

67 Cuthbertson, "The New Great Game," p. 35.

68 Ewan Anderson, "NATO Expansion and Implications for Southern Tier Stability," in Crossroads and Conflict: Security and Foreign Policy in the Caucasus and Central Asia, ed. Garry K. Bertsch, Cassady B. Craft, Scott A. Jones and Michael D. Beck (New York: Routledge, 2000), 130.

69 Lieven, "The (Not So) Great Game."

70 Lieven, "The (Not So) Great Game."

71 O'Hara, "Great Game or Grubby Game? The Struggle for Control of the Caspian."

72 Petar Kurecic, "The New Great Game: Rivalry of Geostrategies and Geoeconomics in Central Asia," Hrvatski Geografski Glasnik 72, no. 1 (2010): 21-48. 
and Turkey." 73 Markedonov notes that the rising tensions between the US-led West and Russia globally are mirrored in the South Caucasus, where there is the risk of more disagreements, and even the possibility of a conflict cannot be completely ruled out. ${ }^{74}$

\section{Conclusion}

There is a significant difference in the apparent value of policy and influence by Russia and NATO, whereas the South Caucasus is regarded as critical for Russia's interests and security. The five-day war in Georgia in 2008 and the annexation of Crimea in 2014 showed that Russia has returned to the arena with a sense of purpose and proved its assertiveness through its actions. Neither Georgia nor Ukraine was the issue in these wars. These two countries served as the playground for a bigger geopolitical game that has been going on between Russia and the West since the collapse of the Soviet Union. NATO did not come to Georgia's defense in 2008 when war broke out and would be unlikely to do so today. Russia will pull out all the stops in order to exert its influence in its "Near Abroad" and reassert itself as a dominant power like elsewhere in the post-Soviet space. With its proximity to Russia, the South Caucasus occupies the first place in this "near abroad." The only way for South Caucasus countries (Georgia and Azerbaijan) to eradicate their problems regarding frozen conflicts is to strike the right balance between NATO and Russia, because the latter does not give up its political ambitions in the region. But the cooperation with NATO has the utmost importance for all three countries. And since Armenia is a CSTO member, Georgia and Azerbaijan could follow suit by considering the models of Sweden and Finland to enhance further cooperation with NATO.

The Alliance may facilitate and expand Azerbaijani-Georgian military cooperation to enforce peace and stability in the South Caucasus in the foreseeable future through active partnership relations without demanding a request for membership. Since every move that any South Caucasus country makes towards NATO membership might prompt a negative reaction from Russia, NATO will be reluctant to respond to every Russian action, as it did during the 2008 GeorgianRussian war. Thus, close practical cooperation with NATO without aiming at membership will improve both Azerbaijan's and Georgia's defense capabilities. This kind of strategy will reduce the ongoing tension between Russia and the West and may partially balance Russia's military presence in Armenia, as well as in Georgia's breakaway regions. Europe is vulnerable to energy coercion, and Azerbaijan-Georgia-Turkey cooperation offers it the best option to withstand this coercion. Maintaining security in the region is in the interest of energy-importing, transit, and energy-exporting countries, which need to ensure the secu-

73 Antonopoulos, Velez, and Cottle, "NATO's Push into the Caucasus: Geopolitical Flashpoints and Limits for Expansion," p. 376.

74 Sergey Markedonov, "Russian Policy Toward the South Caucasus: Security, Unity, and Diversity," 148. 
rity of their industry and pipeline infrastructure. That is why the South Caucasus region has to be considered a buffer zone between NATO and Russia until the "frozen conflicts" are settled, and all energy projects are implemented. Choosing only one side can only bring to Georgia and Azerbaijan headache and exacerbate the existing crises in their territories.

In the bigger strategic picture and to address the research question that was posed at the beginning of this article, can one claim that a New Great Game really occurs? The answer is not a simple yes or no, but a more nuanced picture that lands somewhere in-between these extremes. Competition for power and influence in the South Caucasus by foreign powers is clearly observable, and especially between the actors focused upon in this article, namely Russia and NATO. The other side's actions are perceived as equally provocative by both NATO and Russia, even if respective processes and events occur beyond the region of the South Caucasus and in need of some sort of firm policy response. However, in the current New Great Game, which is a contested term and phenomenon, there are some significant differences forming the very basis of the great power conflict and competition. The Old Great Game concerned two great powers clashing over "unclaimed" land as they progressively moved closer towards each other. At its roots, the New Great Game transpired due to the collapse of the Soviet Union, which opened up an area that has been in Russia's orbit for some 200 years to the influence of other foreign actors. The Old Great Game very much involved the direct occupation and colonization of territory. Whereas the New Great Game concerns the pursuit of influence of countries through the use of institutions - NATO, GUAM, EU versus CIS, CSTO, and Eurasian Union. This clash of institutions of the opposing sides also reveals a clash of values and approaches. Euro-Atlantic organizations emphasize the transfer of values and norms that are meant to transform the host country into an entity that is more 'like-minded' in the liberal democracy spectrum. Those organizations associated with Russia tend to be less demanding on the need for transformation, tending instead to support the status quo. As to the most striking similarity, at its very heart of intent, the New Great Game is like the Old Great Game, involving a deliberate attempt to try to exclude the geopolitical and geo-economic success or even the presence of competing actors from a specific geographical region.

\section{Disclaimer}

The views expressed are solely those of the authors and do not represent official views of the PfP Consortium of Defense Academies and Security Studies Institutes, participating organizations, or the Consortium's editors.

\section{Acknowledgment}

Connections: The Quarterly Journal, Vol. 18, 2019 is supported by the United States government. 


\section{About the Authors}

Khayal Iskandarov is the head of the Editorial section at the War College of the Armed Forces of the Republic of Azerbaijan. He completed his PhD education in the specialty of "National security and military sciences" in 2018. He defended a PhD thesis titled "National Security of the Republic of Azerbaijan and NATO." Khayal Iskandarov is the author of approximately 100 scientific papers.

E-mail: xayal1333@gmail.com

Assoc. Prof. Greg Simons, PhD, is a researcher at the Institute for Russian and Eurasian Studies (IRES) at Uppsala University, Sweden, and a lecturer at the Department of Communication Sciences at Turiba University in Riga, Latvia. His research interests include Russian mass media, public diplomacy and soft power, crisis management communications, media, and armed conflict. He is the author of numerous refereed articles, chapters, and books.

E-mail: greg.simons@ires.uu.se

Piotr Gawliczek, Ph.D., is an Associate Professor of the University of Warmia and Mazury in Olsztyn and NATO DEEP Advance Distance Learning portal coordinator. His research and educational activities are focused on innovative solutions in education and training. He has written numerous publications on the topics of ICT, e-learning, Bologna Process, asymmetric threats, and leadership. He has implemented e-learning/ADL system solutions, based on the LMS ILIAS platform, in many military and civilian educational entities.

E-mail: pgawliczek@gmail.com 